\title{
Effect of Different Transplanting Dates on Productivity and Water Expense Efficiency in Rice (Oryza sativa L.)
}

\author{
Karanjeet Singh, Balwinder Singh Dhillon* and Ajmer Singh Sidhu \\ College of Agriculture, Guru Kashi University, Talwandi Sabo, Punjab, India \\ *Corresponding author
}

\section{Keywords}

Rice, Grain yield, Transplanting dates and water-expenseefficiency

Article Info

Accepted:

12 April 2019

Available Online:

10 May 2019

\section{A B S T R A C T}

A field experiment entitled "Effect of different transplanting dates on productivity and water use in rice (Oryza sativa L.)" was conducted at Research Farm, Department of Agronomy, Guru Kashi University, Talwandi Sabo during Kharif season 2017 and 2018. The experiment was conducted in randomized complete block design with four transplanting dates (June 25, July 5, July 15 and July 25), replicated with five times. The soil of the experimental field was loamy sand, with neutral in reaction, low in organic carbon and available nitrogen, medium in available phosphorous and high in available potassium. Transplanting crop on June 25 gave maximum plant height and number of tillers than other transplanting dates. Transplanting paddy crop on June 25 gave significantly higher yield attributes i.e. effective tillers, number of grains per panicle, panicle length, 1000-grain weight, grain yield, straw yield and harvest index than other transplanting dates. Early paddy transplanting (June 25) obtained $41.1 \%$ higher grain yield than later transplanting date (July 25). June 25 resulted in more water use $(243.4 \mathrm{~cm})$ followed by July $5(230.8 \mathrm{~cm})$, whereas July 25 recorded the lowest water use $(204.7 \mathrm{~cm})$. Transplanting paddy on June 25 recorded highest water-expense-efficiency as compared to other transplanting dates but it was statistically at par with July 5 .

\section{Introduction}

Rice (Oryza sativa L.) is the most important staple food crop of India and it covers $32 \%$ of cropped area in Asia. India ranked second after China in rice production. Globally, production of rice is estimated at a new record of 110.2 million tonnes harvested from 43.2 million hectares and productivity was 25.5 $\mathrm{q} / \mathrm{ha}$. It was grown in area of 43.5 million hectares with production of 104.41 million tonnes and productivity was $24.0 \mathrm{q} / \mathrm{ha}$ in
India. In Punjab rice is a major kharif crop and widely grown under many different conditions and production systems, but submerged in water is the most common method.

Rice is the cereal crop that can grow for long periods of time in standing water. So water becomes one of the most important components for sustainable rice production in major rice producing areas of country as well as world. Rice is grown widely grown in India 
in more than 20 states, on an area of over 400 lakh hectares. With the green revolution attained post-independence, India has been able to produce enough rice to meet the requirements of its burgeoning population. Rice is a semi aquatic plant that requires near sub-mergence conditions for its growth. The sub-mergence also helps to suppress weed growth and availability of nutrients. Daily consumptive use of water require for rice is 6 to $10 \mathrm{~mm} /$ day and 2000 to 3000 liters of water required to produce $1 \mathrm{~kg}$ of rice. The evapotranspiration is the prime component in a field water balance and needs to be accurately quantified. The climate data are used for estimating irrigation water requirement even sufficient water resource, irrigation can substantially increase crop yield, but again the scheduling of the water availability is usually based on estimates of evapo-transpiration (Doorenbos and Pruitt, 1977).

Increased water use efficiency of field crops can be possible through proper irrigation scheduling to match the crop evapotranspiration and providing irrigation at critical growth stages (Hunsaker et al., (1996), Norwood and Dumler (2002) reported that the effect of planting dates on grain yield and some agronomic characters by early seeding (June 15 and June 30) and late seeding (July 15 and July 30). The earlier studies indicated that planting date affected the performance of these traits significantly (Vange and Obi, 2006). Khalifa (2009) found that early sowing of rice recorded maximum tillering, panicle initiation, heading date, number of tillers/plant, plant height and root length at panicle initiation and heading stage, chlorophyll content, number of days to panicle initiation and heading date, leaf area index, sink capacity, spikelets/leaf area ratio, number of grains per panicle, panicle length $(\mathrm{cm}), 1000$ grain weight $(\mathrm{g})$, number of panicles $\mathrm{m}^{-2}$, panicle weight $(\mathrm{g})$ and grain yield ( $\mathrm{t} / \mathrm{ha}$ ). This will certainly cause a serious problem for future sustainability. Therefore there is an immediate and urgent need to reduce the water consumption especially during the early establishment of the crop after transplanting. So there is a serious need to test the delaying of transplanting of the crop by at least 10-15 days late transplanting (from $15^{\text {th }}$ June to $25^{\text {th }}$ June), which is quite dry, hot and highly evaporating period. Rice, being a major kharif season crop of this area requires a study of water efficiency and its association with different weather parameters. In view of above consideration the present investigation was planned to evaluate the effect of different transplanting dates on productivity and water expense efficiency in rice.

\section{Materials and Methods}

The present investigation entitled "Effect of different transplanting dates on productivity and water expense efficiency in rice (Oryza sativa L.)" was conducted at experimental farm of Guru Kashi University Talwandi Sabo, Bathinda during kharif season 2017 and 2018. Talwandi Sabo is located at $29^{0} 57^{\prime} \mathrm{N}$ latitude and $75^{\circ} 7^{\prime} \mathrm{E}$ longitude and altitude of 213 meters above the sea level. The soil of the experimental plot was sandy loam with a $\mathrm{pH}$ of 7.9 , low in organic carbon $(0.30 \%)$, low in available $\mathrm{N}\left(234.2 \mathrm{~kg} \mathrm{ha}^{-1}\right)$, medium in available $\mathrm{P}\left(15.1 \mathrm{~kg} \mathrm{ha} \mathrm{ha}^{-1}\right)$ and high in available K (290.6 kg ha $\left.{ }^{-1}\right)$.

The experiment was laid out in randomly block design with five replications. The treatments comprised of four transplanting dates (25 June, 5 July, 15 July and 25 July) Nitrogen, phosphorus, potassium, and zinc were applied at 105:30:30 $\mathrm{kg}$ of $\mathrm{N}: \mathrm{P}: \mathrm{K} / \mathrm{ha}$ respectively in each plot in the form of urea, single super phosphate and muriate of potash. Full dose of phosphorus and potassium were applied basal in all the treatments. Half dose 
of nitrogen was applied on standing crop at two weeks after sowing by top dressing. Remaining half nitrogen was applied in two equal splits at 20 and 40 DAS.

Plant height of randomly selected five plants was measured in each plot at the time of maturity from the base of the stem at ground level to the base of main panicle of rice. Total number of tillers of five randomly selected plants was recorded from the each plot at the time of maturity. The no. of productive tillers from randomly selected five plants in each plot was counted. The length of the panicle was measured from the base of panicle to the tip of panicle from the five randomly selected plants in each plot. The no. of grains per panicle was counted from five randomly selected panicles. The mean number of grains per panicle was calculated. The number of plants at maturity was recorded on alternate days from every plot. The data on which about more than $70 \%$ of plants got maturity was taken as the date of maturity. The samples of 1000-grains were drawn from each plot after cleaning mean value was worked out after recording their weight. The weight of total production from the net plot was recorded after harvest with help of electronic balance. The weight of the grain per net plot was record in kilogram after threshing of the produce. Later on it was converted into grain yield ( $q /$ ha). The straw yield was worked out from the weight of total biomass and expressed $\mathrm{q} / \mathrm{ha}$. The biological yield was calculated by the addition of grain yield and straw yield. The harvest index was calculated with the help of following formula

$$
\text { HI }(\%)=\frac{\text { Grain yield }(\mathrm{q} / \mathrm{ha})}{\text { Biological yield }(\mathrm{q} / \mathrm{ha})}
$$

Water used data was recorded plot wise from the field with the help of scale. The water expenses efficiency was calculated by using the following formula
Water Expense Efficiency $($ WEE$)=$

Grain yield (kg/ha)

Amount of water used $(\mathrm{cm})$

\section{Results and Discussion}

\section{Growth parameters of rice}

The results showed the significant effect of plant on height (Table 1). Accordingly, out of different sowing dates the earliest June 25 recorded the highest plant height being significantly higher than July 5, July 15 and July 25 transplanting dates. The shortest plant height $(117.0 \mathrm{~cm})$ was recorded in July 25 transplanting date. The reduction in plant height may be due to decreasing temperature and day length. Khade et al., (1997) also reported similar results. The decreased plant height with delay in sowing was also reported by Safdar et al., (2013). The highest plant height $(135.3 \mathrm{~cm})$ at harvested was recorded in June 25 may be assigned due to favourable climate condition and long growth period for better growth and higher nutrient uptake.

Out of different sowing dates the earliest June 25 recorded the higher number of tillers (14.7) per plant, being significantly higher than July 5, July 15 and July 25 transplanting dates. The minimum number of tillers (9.6) per plant was recorded in July 25 transplanting date. The number of tillers significantly less with delayed planting was also reported by Patel (1999), Rai and Kushwaha (2008).

\section{Phenology of rice}

Number of days taken to $50 \%$ flowering (100.0) was significantly higher in June 25 transplanting date than July 5, July 15 and July 25. The increase in no. of days taken to $50 \%$ flowering may be assigned due to better growth attributes. Similar results have been 
reported by Singh et al., (2008). The lowest number of days taken to $50 \%$ flowering (93.4) was recorded on July 25.

The June 25 took more number of days taken to maturity (133.4) which was significantly higher than July 5, July 15 and July 25 transplanting dates. The minimum number of days taken to maturity (122.0) was recorded in July 25. Although the delayed sowing the number of days to maturity were more but the difference was much less than the difference in number of days between the dates of planting. This might be due to the reason that the maturity is affected by the temperature and day length which go on decreasing towards maturity. This trend has also been reported by Rai and Kushwaha (2008) and Khalifa and El-Rewainy (2012).

\section{Yield attributes}

The results indicate that dates of transplanting showed the significant effect on number of effective tillers per plant. Out of different sowing dates the earliest June 25 was recorded the highest number of effective tillers (13.1) per plant, being significantly higher than July5, July 15 and July 25 transplanting dates. The lowest number of effective tillers (8.6) per plant was recorded in $25^{\text {th }}$ July $\left(\mathrm{D}_{4}\right)$ transplanting. This shows the decreasing trend for this character with the delay in transplanting. First date of sowing (June 25) attained the maximum panicle length $(25.2 \mathrm{~cm})$, which was significantly higher than July 5, July 15 and July 25 transplanting dates. The lowest panicle length $(20.0 \mathrm{~cm})$ was noted from July 25 transplanting date.

The earliest June 25 recorded the higher number of grains per panicle (253.5), being significantly higher than July 5, July 15 and July 25 transplanting dates. The minimum number of grains per panicle (206.4) was recorded under the July 25 transplanting date. The delayed sowing of rice adversely affected yield attributes may be due to decreased grain filling period. Earliest June 25 recorded maximum weight of 1000-grains (30.3 g), being significantly higher than July 5, July 15 and July 25) transplanting dates. The minimum 1000 -grain weight $(25.0 \mathrm{~g})$ was recorded in July 25 transplanting date. The early sowing was reported to be the appropriate time for the expression of characters (Khalifa, 2009). Heavier 1000grain weight under early sowing than the late sowing has also been reported by Mohapatra et al., (1997) and Bashir et al., (2010).

\section{Productivity of rice}

The earliest June 25 recorded the highest grain yield (80.4 q/ha), being significantly higher to July 5, July 15 and July 25 transplanting dates. The minimum grain yield (60.4 q/ha) was recorded from July 25 transplanting date. There was loss in grain yield with further delay in sowing (Manjappa and Kumar, 2002).

Out of sowing dates the earliest June 25 transplanting date attained the highest straw yield (183.15 q/ha) being significantly higher to July 5, July 15 and July 25 transplanting dates. The lowest straw yield (152.6 q/ha) was recorded from July 25 transplanting date. Early sowing dates produced higher straw yield than delayed planting (Hussain et al., 2009). This can be expected the early sown crop gets suitable environment in terms of temperature and photoperiod.

Earliest June 25 transplanting date recorded the maximum biological yield (263.5 q/ha), being significantly highest than July 5, July 15 and July 25 transplanting dates. The lowest biological yield (213.0 q/ha) was noted from July 25 transplanting dates. 
Table.1 Effect of different transplanting dates growth parameters, yield attributes and productivity of rice (Pooled data over 2 years)

\begin{tabular}{|c|c|c|c|c|c|c|c|c|c|c|c|c|}
\hline Treatment & $\begin{array}{c}\text { Plant } \\
\text { height } \\
(\mathrm{cm})\end{array}$ & $\begin{array}{c}\text { No. of } \\
\text { tillers } \\
\text { per } \\
\text { plant }\end{array}$ & $\begin{array}{c}\text { No. of } \\
\text { effective } \\
\text { tillers } \\
\text { per } \\
\text { plant }\end{array}$ & $\begin{array}{c}\text { Panicle } \\
\text { length } \\
\text { (cm) }\end{array}$ & $\begin{array}{c}\text { Number } \\
\text { of } \\
\text { grains/ } \\
\text { panicle }\end{array}$ & $\begin{array}{c}\text { Number } \\
\text { of days } \\
\text { taken to } \\
50 \% \\
\text { flowering }\end{array}$ & $\begin{array}{c}\text { Number } \\
\text { of days } \\
\text { to } \\
\text { maturity }\end{array}$ & $\begin{array}{c}\text { 1000- } \\
\text { grain } \\
\text { weight } \\
\text { (g) }\end{array}$ & $\begin{array}{c}\text { Grain } \\
\text { yield } \\
\text { (q/ha) }\end{array}$ & $\begin{array}{c}\text { Straw } \\
\text { yield } \\
\text { (q/ha) }\end{array}$ & $\begin{array}{c}\text { Biological } \\
\text { yield } \\
\text { (q/ha) }\end{array}$ & $\begin{array}{c}\text { Harvest } \\
\text { index } \\
(\%)\end{array}$ \\
\hline June 25 & 135.3 & 14.7 & 13.1 & 25.2 & 253.5 & 100.0 & 133.4 & 30.3 & 80.4 & 183.2 & 263.5 & 30.5 \\
\hline July 5 & 131.6 & 13.2 & 12.2 & 23.8 & 244.0 & 99.2 & 128.4 & 28.3 & 75.5 & 168.6 & 244.1 & 30.9 \\
\hline July15 & 124.6 & 11.7 & 10.8 & 21.6 & 226.3 & 96.2 & 124.2 & 26.5 & 68.6 & 158.1 & 226.7 & 30.3 \\
\hline July 25 & 117.0 & 9.6 & 8.6 & 20.0 & 206.4 & 93.4 & 122.0 & 25.0 & 60.4 & 152.6 & 213.0 & 28.4 \\
\hline $\begin{array}{c}\text { LSD } \\
(\mathrm{P}=\mathbf{0 . 0 5})\end{array}$ & 2.4 & 0.8 & 0.5 & 1.1 & 10.5 & 2.0 & 1.7 & 1.1 & 4.3 & 5.8 & 6.0 & 0.5 \\
\hline
\end{tabular}

Table.2 Effect of different date of transplanting on water productivity in rice (Pooled data over 2 years)

\begin{tabular}{|l|c|c|}
\hline \multicolumn{1}{|c|}{ Treatment } & $\begin{array}{c}\text { Water used } \\
(\mathbf{c m})\end{array}$ & $\begin{array}{c}\text { Water expense efficiency } \\
(\mathbf{k g} / \mathbf{c m})\end{array}$ \\
\hline June 25 & 243.4 & 33.8 \\
\hline July 5 & 230.8 & 31.8 \\
\hline July15 & 217.3 & 29.3 \\
\hline July25 & 204.7 & 28.5 \\
\hline LSD $(\mathbf{P = 0 . 0 5 )}$ & $\mathbf{3 . 5}$ & $\mathbf{1 . 3}$ \\
\hline
\end{tabular}


The trend of decreasing yield under the delayed transplanting can be due to the availability of suitable temperature and photoperiod under the early transplanting dates.

The dates of transplanting show the significant effect on harvest index. Earliest 25th June (D1) transplanting date higher harvest index (30.5\%), and significantly higher than July 5, July 15 and July 25 transplanting dates. The lowest harvest index (28.4\%) was observed in July 25 transplanting date. The early sowing dates produced higher harvest index than delayed transplanting similar results were also represented by Hussain et al., (2009).

\section{Water productivity of rice}

\section{Water use}

The effect of date of sowing on amount of water used for paddy crop was significantly different (Table 2). The water use efficiency for sowing in June $25(243.4 \mathrm{~cm})$ was significantly higher than July 5, July 15 and July 25. The lowest water used $(204.7 \mathrm{~cm})$ was calculated from July 25 transplanting date.

\section{Water expense efficiency}

The effect of date of sowing on water expense efficiency for paddy crop was significantly different (Table 2). The water expense efficiency for sowing in June $25(33.8 \mathrm{~kg} / \mathrm{cm})$ was significantly higher than the July 5 , July 15 and July 25. Minimum water expense efficiency $(28.5 \mathrm{~kg} / \mathrm{cm})$ was noted in the July 25 transplanting date.

In conclusion, earlier transplanting date (June 25) gave significantly higher plant height, number of tillers, yield attributes and grain yield than other transplanting dates (July 5,
July 15 and July 25). June 25 transplanting dates recorded highest water-expenseefficiency as compared to other transplanting dates (July 5, July 15 and July 25).

\section{References}

Bashir, M.Usman., Akbar, N., Iqbal, A. and Zaman, H. (2010). Effect of Different Sowing Dates on Yield and Yield Components of Direct Seeded Coarse Rice (Oryza sativa L.).Pak. J. Agri. Sci. 47(4): 361-365.

Doorenbos J and Pruitt WO. (1977). Guidelines for predicting crop water requirement: FAO irrigation and drainage paper No. 24, FAO, Rome Italy. 156p.

Hunsaker DJ, Kimball BA, Pinter Jr PJ, La Morte RL and Wall GW. (1996). Carbon dioxide enrichment and irrigation effects on wheat evapotranspiration and water use efficiency. Trans. ASAE, 39: 13451355.

Hussain, A., Bhat, M.A., Ganai, M.A. and Hussain, T. (2009). Influence of planting date sand spacing schedules on performance of Basmati rice Pusa Sugandh-3 under Kashmir valley condition. Environment and Ecology. 27(1A): 396-398.

Khade VN, Patil BP, Jadhav SN and Khanvilakr S. (1997). Effects of climatic factors on rice yield potential and grain shape by delayed sowing. Maharashtra J Agrometerol., 4(4): 20719.

Khalifa A.A.B.A. (2009). Physiological evaluation of some hybrid rice varieties under different sowing dates. Aust. J. C., Pp. 78-183.

Khalifa, A.A. and El-Rewainy, I.M. (2012). Study some physiological characters, yield and yield component for five new rice varieties under different sowing 
dates. Advances in Applied Science Research. 3(1): 440-445.

Manjappa, K. and Kumar, P. (2002). Performance of rained transplanted rice under different dates of planting in hilly zone of Karnataka. Karnataka Journal of Agricultural Sciences. 15(1): 136138.

Mohapatra, A.K., Paikaray, R.K. and Haldar, J. (1997) Response of extra-early rice varieties to sowing time and fertilizer levels. Oryza 34: 75-76.

Norwood CA and Dumler TJ. (2002). Transition to dry land agriculture. Limited irrigation vs. dry land corn. Agronomy Journal 94: 310-320.

Patel JR. (1999). Response of rice to time of transplanting, spacing and age of seedlings. Indian Journal of Agronomy. 44 (2):344-46.
Rai HK and Kushwaha HS. (2008). Effect of planting dates and soil water regimes on growth and Yield of upland rice. Oryza - An International Journal on Rice. 45(2):129-32.

Safdar, M.E., Noorka, I.R., Tanveer, a., Tariq, S.A. and Rauf, S. (2013). Growth and Yield of Advanced Breeding Lines of Medium Grain Rice as Influenced by Different Transplanting Dates. The Journal of Animal \& Plant Sciences. 23(1): 227-231.

Vange T. and I.U. Obi. (2006). Effect of planting date on some agronomic traits and grain yield of upland rice varieties at Makurdi, Benue state, Nigeria. J. Sust. Develop. Agric. Environ. 2(1): 19.

\section{How to cite this article:}

Karanjeet Singh, Balwinder Singh Dhillon and Ajmer Singh Sidhu. 2019. Effect of Different Transplanting Dates on Productivity and Water Expense Efficiency in Rice (Oryza sativa L.). Int.J.Curr.Microbiol.App.Sci. 8(05): 1480-1486. doi: https://doi.org/10.20546/ijcmas.2019.805.170 